\title{
KORELASI PELAYANAN GEMBALA TERHADAP \\ PERTUMBUHAN ROHANI PERKARIA DI GEREJA \\ KEMAH INJIL INDONESIA JEMAAT MAZMUR \\ DATAH BILANG ULU
}

\author{
Robert Dabili, Yunus D. A. Laukapitang
}

\begin{abstract}
Abstrak
Gembala yang baik adalah gembala yang merawat dan memelihara kawanan domba dengan sepenuh hati bahkan rela mengorbankan nyawanya demi domba-dombanya (Yohanes 10:11). Tugas pengembalaan adalah tugas yang dipercayakan oleh Allah untuk melaksanakan sesuai dengan petunjuk dan ketetapan dari Allah sendiri. Tujuan penulisan ini untuk menjelaskan apa konsep pelayanan gembala terhadap pertumbuhan rohani Perkaria di Gereja Kemah Injil Indonesia Jemaat Mazmur Datah Bilang Ulu dan untuk menjelaskan bagaimana konsep pelayanan gembala meningkatkan pertumbuhan rohani Perkaria di Gereja Kemah Injil Indonesia Jemaat Mazmur Datah Bilang Ulu. Maka dengan mengunakan metode kuantitatif untuk mengumpulkan data-data. Adapun isi dalam penulisan ini untuk membahas pelayanan gembala dan pertumbuhan rohani serta mengumpulkan data-data yang terjadi antara hubungan pelayanan gembala terhadap pertumbuhan rohani kaum Perkaria di Jemaat Mazmur Datah Bilang Ulu.
\end{abstract}

Kata-kata Kunci: Pelayanan, Gembala, Pertumbuhan, Rohani, Perkaria

\section{Pendahuluan}

\section{Latar Belakang Masalah}

Konsep tentang gembala sebenarnya sudah ada sejak mulai penciptaan di Taman Eden setelah Allah menciptakan manusia pertama itu. Allah segera berperan dan bertang-gung jawab terhadap apa yang Ia jadikan. Allah bukan hanya sekedar menciptakan manusia itu, lalu membiarkanya berjalan sendiri, melainkan mendelegasikan tugas kepada mereka dan mereka bertanggung jawab kepada Allah sebagai gembala. ${ }^{1}$

Pelayanan gembala itu sangat penting bagi orang Kristen. Oleh sebab itu, Dr. M. Bons-Storm mengutip dari bukunya Thurnesysen, bahwa: "Penggembalaan merupakan suatu penerapan khusus Injil kepada anggota jemaat secara pribadi, yaitu

${ }^{1}$ Yanda Kosta \& Jermia Djadi, "Peran Gembala Sebagai Pemimpin Dalam Perspektif I Petrus 5:1-4 dan Relevansinya Pada Masa Kini,” Jurnal Jaffray 9, No. 2 (Oktober 2011): 172. 
berita Injil yang dalam khotbah gereja disampaikan kepada anggota jemaat.",2 Penggembalaan adalah menolong setiap orang untuk menyadari hubungannya dengan Allah, dan mengajar orang untuk mengakui ketaatannya kepada Allah dan sesama manusia.

Gembala yang baik adalah gembala yang merawat dan memelihara kawanan domba dengan sepenuh hati bahkan rela mengorbankan nyawanya demi dombadombanya (Yohanes 10:11). Tugas penggembalaan adalah tugas yang dipercayakan oleh Allah untuk melaksanakan sesuai dengan petunjuk dan ketetapan dari Allah sendiri. ${ }^{3}$ Penggembalaan merupakan bagian yang tidak terpisahkan dari tugas-tugas dan pelayanan gereja. ${ }^{4}$ Penggembalaan memiliki kaitan atau hubungan untuk saling melengkapi dalam usaha untuk menumbuhkan dan mengembangkan kerohanian jemaat.

Peranan gembala selain bagi pekabaran Injil kepada orang-orang yang belum di selamatkan, juga sangat penting bagi pembangunan tubuh Kristus di dunia ini, terutama dalam membangun kehidupan rohani jemaatnya agar bertumbuh menjadi jemaat yang dewasa rohaninya. Dan pertumbuhan gereja adalah meliputi segala sesuatu yang ada sangkut pautnya dalam usaha membawa orang-orang yang tidak mempunyai hubungan pribadi dengan Yesus Kristus kepada persekutuan dengan jemaat. Dan membawa mereka menjadi anggota gereja yang bertanggung jawab. ${ }^{5}$ Gembala tidak lagi merasa puas dengan pelayanan mimbar, karena hampir setiap anggota jemaatnya masih membutuhkan bimbingan pribadi untuk bertumbuh bahkan mengalahkan hambatan-hambatan dalam kehidupan rribadi jemaat. $^{6}$

Demikian juga pertumbuhan rohani Perkaria Jemaat Mazmur Datah Bilang Ulu di Kalimantan Timur sangat merosot rohaniannya. Oleh sebab itu, bapak Tingai Njau mengatakan bahwa, kurangnya kekompakkan dan persatuan di antara anggota Perkaria serta ada yang lebih mengutamakan hal-hal duniawi dari pada yang bersifat rohani, menyebabkan terjadi penghambatan pertumbuhan rohaninya bagi persekutuan Perkaria. ${ }^{7}$ Kemerosotan pertumbuhan rohani Perkaria dapat dilihat dari kehadiran Perkaria dalam mengikuti kegiatan ibadah Perkaria. Perkaria kurang sekali hadir dalam persekutuan yang dilakukan dibandingkan dengan jumlah anggota seluruhnya.

Menurut Tanjung Lahang, selaku ketua Perkaria mengatakan bahwa: Ini karena kurangnya perhatian dari gembala terhadap Perkaria, sendiri menjadi bingung mengapa ibu gembala tidak sama sekali membina Perkaria agar maju seperti organisasi yang lain. Pelayanan belum pernah mulai sesuai dengan harapan dan kebutuhan anggota Perkaria. Selama periode saya menjadi ketua perkaria dari tahun 2014-2018, kehadiran mengikuti ibadah Perkaria paling banyak 46 orang dari jumlah keseluruhan yang ada ratusan anggota. ${ }^{8}$

\footnotetext{
${ }^{2}$ M. Bons-Storm, Apakah Pengembalaan Itu? (Jakarta: BPK Gunung Mulia, 2012), 1.

${ }^{3}$ Calvin Sholla Rupa, "Ciri Khas Seorang Gembala Berdasarkan Prespektif I Petrus 5:1-4," Jurnal Jaffray 14, No. 2 (Oktober 2016): 165-186.

${ }^{4}$ Seth Masweli dan Donald Crider, Gembala Sidang dan Pelayanannya (Bandung: Kalam Hidup, 2002), 19.

${ }^{5}$ Helen Farida, "Pengaruh Pengajaran dan Persekutuan Terhadap Tingkat Pertumbuhan Rohani," Jurnal Teologi dan Pelayanan Kristiani 1, No. 2 (November 2017): 119.

${ }^{6}$ Yakub B. Susabda, Pastoral Konseling (Malang: Gamdum Mas, 2003), 1.

${ }^{7}$ Tingai Njau, Wawancara Oleh Penulis, Datah Bilang Ulu, Kec. Long Hubung, Kalimantan Timur, 15 April 2018.

${ }^{8}$ Tanjung Lahang, Wawancara Oleh Penulis, Datah Bilang Ulu, Kecamatan Long Hubung Kalimantan Timur, 13 April 2018.
} 
Penulis lihat yang lebih dominan, yaitu kurang kekompakan dan kurang persatuan, keberadaan Perkaria secara rohani dapat dikatakan merosot. Kenyataan ini membuktikan bahwa pembinaan kerohanian Perkaria tidak diperhatikan secara serius oleh gembala. Melihat kenyataan ini dapat dipertanyakan apakah anggota Perkaria tersebut sudah bertumbuh secara rohani.

Berdasarkan uraian diatas, maka penulis untuk menyusun karya ilmiah dengan judul: KORELASI PELAYANAN GEMBALA TERHADAP PERTUMBUHAN ROHANI PERKARIA DI GEREJA KEMAH INJIL INDONESIA JEMAAT MAZMUR DATAH BILANG ULU.

\section{Pokok Masalah}

Yang menjadi pokok masalah dalam penulisan skripsi adalah:

Pertama, apa konsep korelasi pelayanan gembala terhadap pertumbuhan rohani Perkaria Gereja Kemah Injil Indonesia Jemaat Mazmur Datah Bilang Ulu.

Kedua, bagaimana konsep korelasi pelayanan gembala terhadap pertumbuhan rohani Perkaria Gereja Kemah Injil Indonesia Jemaat Mazmur Datah Bilang Ulu.

\section{Tujuan Penelitan}

Tujuan utama dalam penulisan skripsi adalah:

Pertama, untuk menjelaskan apa konsep pelayanan gembala terhadap pertumbuhan rohani Perkaria di Gereja Kemah Injil Indonesia Jemaat Mazmur Datah Bilang Ulu.

Kedua, untuk menjelaskan bagaimana konsep pelayanan gembala meningkatkan pertumbuhan rohani Perkaria di Gereja Kemah Injil Indonesia Jemaat Mazmur Datah Bilang Ulu.

\section{Manfaat Penelitian}

Manfaat penulisan skripsi adalah:

Pertama, menambah pengenalan yang lebih baik tentang pelayanan Perkaria di Jemaat Mazmur Datah Bilang Ulu.

Kedua, di harapkan menjadi uraian yang ilmiah dalam meningkatkan partumbuhan rohani anggota Perkaria Jemaat Mazmur Datah Bilang Ulu.

Ketiga, sebagai salah satu syarat penyelesaian studi di Sekolah Tinggi Filsafat Jaffray Makassar.

\section{Metode Penelitan}

Metode penelitian yang digunakan oleh penulis adalah metode kuantitatif dengan teknik pengumpulan data sebagai berikut:

Pertama, penelitian kepustakaan, dengan mengadakan penelitian dan pengambilan data dari buku-buku, yang ada kaitannya dengan materi yang akan dibahas dalam skripsi ini.

Kedua, pengamatan langsung, dimana penelitian melihat secara langsung fakta yang ada di lapangan.

\footnotetext{
${ }^{9}$ Hasmawaty, 55; Sareong dan Supartini, 29; Serli dan Wijaya, 17.
} 
Ketiga, melalui akses internet, seperti artikel dan jurnal yang berhubungan dengan judul penulis.

\section{Batasan Penelitian}

Mengingat luasnya masalah yang dihadapi mengenai pembinaan kerohanian Perkaria ini, maka penulis membatasi karya tulis ini hanya pada pertumbuhan rohani Perkaria di Gereja Kemah Injil Indonesia Jemaat Mazmur Datah Bilang Ulu Kalimantan Timur.

\section{Sistematika Penulisan}

Sistematika penulisan yang akan diuraikan dalam skripsi ini, adalah sebagai beriku:

Bab Satu, merupakan pendahuluan yang terdiri dari: Latar Belakang Masalah, Pokok Masalah, Tujuan Penelitian, Manfaat Penelitian, Metode Penelitian, Batasan Penelitian dan Sistematika Penulisan.

Bab Kedua, Tinjauan Pustaka: yang menguraikan tentang Pelayanan Gembala Secara Umum: pengertian pelayanan gembala, dasar Alkitab pelayanan gembala berdasarkan pandangan Alkitab Perjanjian Lama dan Perjanjian Baru, BentukBentuk Pelayanan Gembala dalam hal pengajaran, perkunjungan, konseling, dan displin, dalam pengajaran meliputi: pelayanan mimbar, pemahaman Alkitab dan kelompok sel, Tujuan Pelayanan Gembala. Pertumbuhan rohani yang menjelaskan tentang: pengertian pertumbuhan rohani, relasi pertumbuhan rohani meliputi relasi dengan Allah, pribadi, sesama dan lingkungan. Relasi dengan Allah meliputi: doa, membaca Firman Tuhan, bersaksi dan ibadah. Pribadi meliputi: ketaatan dan karakter. Sesama meliputi: mengasihi dan menghormati, dan dengan lingkungan meliputi; beretika lingkungan, menjaga lingkungan dan menjaga alam. Kriteria pertumbuhan rohani, langkah-langkah meningkatkan pertumbuhan rohani dengan cara perkunjungan, pemahaman Alkitab, pembinaan melalui ibadah dan konseling.

Bab Ketiga, Metode penelitian yang menguraikan tentang: gambaran umum lokasi penelitian, sejarah singkat berdirinya Gereja Kemah Injil Indonesia (GKII) Jemaat Mazmur Datah Bilang Ulu, latar belakang Perkaria, kepengurusan kaum Perkaria, kegiatan ibadah Perkaria, kegiatan keseharian Perkaria, jenis penelitian, populasi, sampel, teknik pengumpulan data dan teknik analisa data.

Bab Keempat, analisis hasil penelitian dan pembahasan.

Bab Kelima, penutup yang berisi kesimpulan dan saran-saran dari hasil penulisan penelitian ini.

\section{Kesimpulan}

Berdasarkan hasil penelitian yang dilakukan oleh penulis, maka penulis menyimpulkan ada beberapa faktor yang menghambat pertumbuhan rohani Perkaria di GKII Mazmur Datah Bilang Ulu, dari hubungan pelayanan gembala terhadap kaum Perkaria yaitu: (1) tidak perhatian dari gembala jemaat kepada kaum Perkaria, (2) gembala tidak memiliki visi yang jelas untuk kaum Perkaria, (3) gembala tidak pernah lakukan bentuk pelayanan apapun terhadap kaum Perkaria, (4) karena hanya satu tenaga pelayanan di jemaat besar Mazmur Datah Bilang Ulu, (5) karena semua 
pelayanan dilibatkan pada hari Minggu, maka gembala susah untuk mengatur waktu, (6) dengan kesibukan pribadi gembala.

Bertitik tolak pada faktor-faktor yang menghambat pertumbuhan rohani Perkaria maka untuk memenuhi kebutuhan guna untuk meningkatkan pertumbuhan rohani Perkaria dapat dilakukan pelayanan gembala sebagai berikut:

Pertama, pelayanan pengajaran gembala meningkatkan pertumbuhan rohani kaum Perkaria, mengajari Perkaria dalam kebenaran. Tidak cukup hanya pelayanan mimbar setiap hari Minggu tetapi bisa lakukan dengan pengajaran lain, seperti; pengenalan Alkitab (PA), cerdas cermat Alkitab (CCA), kelompok sel dan lain-lain supaya Perkaria tetap setia kepada Tuhan dan taat untuk melakukan pekerjaan Tuhan.

Kedua, pelayanan konseling untuk menolong kaum Perkaria dalam menghadapi persoalan hidupnya. Gembala dapat melakukan pelayanan konseling pribadi, baik melalui perjumpaan secara langsung atau melalui hand phone dan mendorong kaum Perkaria untuk setia berdoa kepada Tuhan, membaca firman Allah, bersaksi tentang kasih Allah, dan beribadah kepada Tuhan.

Ketiga, dalam perkunjungan pelayan dapat melakukan pendekatan secara pribadi dan membimbing kaum Perkaria. Sebab mereka sangat membutuhkan bantuan dari gembala, untuk membimbing mereka ke arah yang benar.

\section{Saran-saran}

Pertama, gembala perlu memperhatikan pertumbuhan kerohanian kaum Perkaria dengan mengajarkan bagaimana cara untuk kaum Perkaria bertumbuh kembali dalam Tuhan.

Kedua, dari badan pengurus jemaat meminta permohonan kepada pengurus daerah untuk meminta tambahan tenaga pelayanan di Jemaat Mazmur Datah Bilang Ulu. Perkaria.

Ketiga, gereja perlu menetapkan jadwal pelayanan perkunjungan bagi kaum

Keempat, mengadakan pelayanan konseling terhadap kaum Perkaria yang berma-salah, melalui perjumpaan langsung atau melalui hand phone yang tidak dapat dikunjungi.

\section{Kepustakaan}

Abineno, J. L. Ch. Manusia dan Sesamanya di Dalam Dunia. Jakarta: BPK Gunung Mulia, 1990.

. Doa Menurut Perjanjian Baru. Jakarta: BPK Gunnung Mulia, 1992.

Ali, Mohammad. Penelitian Kependidikan: Prosedur dan Strategi. Bandung: Angkasa, 1985.

Arno, Win. \& Thomas. R.M. Perkembangan Pribadi dan Keseimbangan Mental. Bandung: Jemmars, 1979.

Asali, Budi. "Khotbah Ekspositori 1 PETRUS 5:1-4." Diakses 2 November 2018. http:/-www.golgothaministry.org/1petrus/1petrus27.htm.

Ayni, Nurul "Pelayanan Pastoral Dalam Meningkatkan Pertumbuhan Rohani Remaja.”Skripsi S.Th, Sekolah Tinggi Theologia Jaffray Makassar, 2011. 
Brake, Andrew. Spiritual Formation, Menjadi Serupa Dengan Kristus. Bandung: KALAM HIDUP, 2014.

Brill J. Wesley. Tafsiran Surat Ibrani. Bandung: Kalam Hidup,1973.

Berhitu Reinhard, Jeffray. "Peran Gembala Terhadap Pengembangan Pelayanan Holistik Gereja Kemah Injil Indonesia Jemaat Yegar Sahaduta Jayapura." Jurnal Jaffray 12, No. 2 (Oktober 2014): 273-290.

Browning, W. R. F. Kamus Alkitab. Jakarta: BPK Gunung Mulia, 1996.

Cervone, Daniel. Lawrence A. Pervin, \& John, Oliver P. Psikologi Kepribadian, Teori dan Penelitian. Jakarta: Prenada Media Group, 2010.

Chandra, Julius. Hidup Bersama Orang Lain. Yogyakarta: Anggota IKAPI, 1986.

Daldjoeni N. Penduduk Lingkungan \& Masa Depan. Bandung: Alumni, 1977.

Daun, Paulus. D. H. Bertumbuh Dalam Kristus. Manado: Yayasan Daun Family, 1998.

Djadi, Jermia. Diktat Teologi Pastoral. Makassar: Sekolah Tinggi Theologia Jaffray, 2017. Belum dipublikasikan.

Farida, Helen. "Pengaruh Pengajaran dan Persekutuan Terhadap Tingkat Pertumbuhan Rohani." Jurnal Teologi dan Pelayanan Kristiani 1, No. 2 (November 2017): 117-148.

Ferguson, Sinclair B. Pertumbuhan Dalam Anugrah Allah. Surabaya: LRII, 2005.

Fields, Doug. Purpose Driven Youth Ministry. Malang: Gandum Mas, 1998.

Gandel, Kanneth O. Membina Pemimpin Pendidikan Kristen. Malang: Gandum Mas, 2001.

Getz, Gene A. Saling Membangun. Bandung: Kalam Hidup, 1993.

Gintings, E. P. Konseling Pastoral Terhadap Masalah Umum Kehidupan. Bandung: Jurnal Info Media, 2009.

Gunarsa, Singgih D. Konseling dan Psikoterapi. Jakarta: BPK Gunung Mulia, 2009.

Handojo, Jusak. Manual Gereja Sel. Makassar: Filadelfia Blessing, 2015.

Hasmawaty. "Kemampuan Menyimak Anak Melalui Kegiatan Bercerita (Studi Kasus Pada Taman Penitipan Anak Athirah Makassar)." Jurnal Ilmu Teologi dan Pendidikan Agama Kristen 1, no. 1 (Juni 2020): 55-68.

https://ojs.sttjaffray.ac.id/jitpk/article/view/463/pdf_4.

Huwae, Carolis, \& Scheunemann, Rainer. Metode Pelayanan Konseling Pastoral. Abepura: Sekolah Alkitab Malam, 2004.

Jemmi. Jurnal Elektronik Mingguan Mis 6, No. 31 (Agustus 2003). Diakses 13 Februari 2019. http://www.sabda.org/publikasi/misi/2003/31/.

Jim and Rogers Jan. Petunjuk Untuk Bersaksi dengan Efektif. Malang: Badan Penerbitan,1969.

Kamus Besar Bahasa Indonesia

Khitam, Husnul. Kontekstualisasi Teologi Sebagai Basis Gerakan Ekologi. Diakses 3 Desember 2018. https://www. researchgate. net/publication/ 311469017 Kontek-stualisasi_Teologi_sebagai_Basis_Gerakan_Ekologi.

Kisworo, Marsudi W \& Sofana, Iwan. Menulis Karya Ilmiah. Bandung: Informatika, 2017.

Kosta, Yanda \& Djadi Jermia. "Peran Gembala Sebagai Pemimpin Dalam Perspektif

I Petrus 5:1-4 dan Relevansinya Pada Masa Kini.” Jurnal Jaffray 9, No. 2

(Oktober 2011): 172-198.

Krisetya, Mesach. Bela Rasa Yang Dibagirasakan. Jakarta: Duta Ministri, 2015.

Lawrence, Bill. Menggembalakan Dengan Hati. Yogyakarta: ANDI, 2004.

Leland, Ryken Dkk. (ed.). Kamus Gambaran Alkitab. Surabaya: Momentum, 2011. 
Lovett, C. S. Bersaksi Dengan Mudah. Bandung: Kalam Hidup, 1969.

Mahan, Oliver. Gembala Jemaat Yang Sukses. Jakarta: METANOIA, Gunung Sahari, 2002.

Martin \& Bobgan, Deidre. Bimbingan Berdasarkan Firman Allah. Bandung: Kalam Hidup, 1985.

Masweli, Seth dan Donald, Crider. Gembala Sidang dan Pelayanannya. Bandung: Kalam Hidup, 2002.

Mimery, Nehemia. Rahasia Tentang Penggembalaan. Jakarta: Mimery Press, 2012.

Munroe, Myles. Bicara Tentang Hubungan-Hubungan Dalam Hidup Anda. Surabaya: Light Publishing, 2008.

- Bicara Tentang Hubungan-Hubungan Dalam Hidup Anda. Surabaya: Light Publishing, 2008.

Murray Andrew, Bersekutu Erat Dengan Allah. Yogyakarta: Andi 1998.

Natsir, Moh. Metode Penelitian. Jakarta: Ghalia Indonesia. 1988.

Reksadjaja, Bill S. Manusia Dalam Lingkungan. Bandung: Fakultas Psikologi Universitas Padjadjaran, 1979.

Riggs, Ralph M. Gembala Sidang yang Berhasil. Malang: Gandum Mas, 1996.

Riggs, Charlie, Belajar Berjalan Dengan Allah. Jakarta: Persekutuan Pembaca Alkitab, 2005.

. Belajar Berjalan Dengan Iman. Jakarta: Persekutuan Pembaca Alkitab, 2005.

Rupa Calvin Sholla. "Ciri Khas Seorang Gembala Berdasarkan Prespektif I Petrus 5:1-4". Jurnal Jaffray 14, No. 2 (Oktober 2016): 165-188.

Sabda. "Pengertian Pelayanan Holistik." Diakses 16 Oktober 2018. http://alkitab.sabda.-org/resource.php=493=jpz.

Sanders J. Oswald. Kepemimpinan Rohani. Bandung: Kalam Hidup, 2006.

Sareong, Irene Priskila dan Tri Supartini. "Hubungan Komunikasi Interpersonal Guru dan Siswa Terhadap Keaktifan Belajar Siswa di SMA Kristen Pelita Kasih Makassar." Jurnal Ilmu Teologi dan Pendidikan Agama Kristen 1, no. 1 (Juni 2020): 29-42. https://ojs.sttjaffray.ac.id/jitpk/article/view/466/pdf_2.

Serli dan Hengki Wijaya. "Metode Permainan Dalam Meningkatkan Pemahaman Firman Tuhan Pada Remaja GKII Okahapi Sumba Timur." Jurnal Ilmu Teologi dan Pendidikan Agama Kristen 1, no. 1 (Juni 2020): 17-28. https://ojs.sttjaffray.ac.id/jitpk/article/view/459/pdf_1.

Sealy, Susan. 40 Days To Your Best Life For Women. Jakarta: BPK Gunung Mulia, 2010.

Selan, Ruth F. Pembina Warga Jemaat. Bandung: Kalam Hidup, 1994.

Setiawan, Obaja Tanto. Kelompok Sel (Prinsip 12). Solo: Departemen Media GBI Keluarga Tuhan, 2000.

Shelly, Judith Allen. Kebutuhan Rohani Anak. Bandung: Kalam Hidup, 1982.

Shipman, Michael K. Pembaruan Pelayanan Mimbar. Bandung: Kalam Hidup, 2006.

Sidjabat. Membesarkan Anak Dengan Kreatif. Yogyakarta: Andi, 2008.

Singarimbun, Masri dan Effendi, Sofyan. Metode Penelitian Survey. Jakarta: LP3ES, 1985.

Siregar, M. "Hidup Dalam Persekutuan.” Diakses 25 November 2018. http://wwwgkpiorg/-index.php?option=40com.conten\&viewarticle\&id=57\%3 hidupdalam-perseku-tuan $\&$ itemid $=40$. 
Siswoharddjono, Aryatmi. Apakah Faktor-Faktor yang Menentukan Ciri dan Pendeka-tan Dalam Konseling yang Diberikan. Yogyakarta:Andi, 1985.

Stamps, Donald C. (ed.). Alkitab Penuntun Hidup Berkelimpah an. Malang: Gandum Mas, 2010.

Steward (ed.). Bagaimana Menjangkau Orang Percaya. Bandung: Kalam Hidup, 1978.

Storm, M. Bons. Apakah Pengembalaan Itu? Jakarta: BPK Gunung Mulia, 2012.

Strauch, Alexander. Kepenatuaan Atau Kependetaan. Yogyakarta: ANDI, 1992.

Sugiyono. Metode Penelitian Kombinasi. Bandung: ALFABETA, 2014.

Sumanto. Metode Penelitian Sosial dan Pendidikan. Yogyakarta: ANDI Offsett, 1990.

Supardi. Lingkungan Hidup dan Kelestarian. Bandung: Alumni 1980.

Supratiknya A. Komunikasi Antar Pribadi. Yogyakarta: Kanisius, 1995.

Susabda, Yakub B. Pastoral Konseling. Malang: Gamdum Mas, 2003.

Team ISCW Philippina. Langkah-Langkah Pertumbuhan Iman. Jakarta: Persekutuan Kristen Antar Universitas, 2004.

The Navigators. (ed.). Memimpin Kelompok Penelahan Alkitab. Jakarta: BPK Gunung Mulia, 1996.

Thom and Schultz, Joani. Meningkatkan Kinerja Jemaat. Bandung: Kalam Hidup, 2000.

Tim Dosen dan Alumni Sekolah Tinggi Theologia Jaffray Makassar \& Ronda, Daniel. Utuslah Aku. Bandung: Kalam Hidup, 2012.

Tomatala, Y. Penatalayanan Gereja Yang Efektif. Malang: Gandum Mas, 1993.

Tong, Stephen. Keseimbangan Dalam Pelayanan Kristen. Surabaya: YAKIN, 1976. . Arsitek Jiwa. Jakarta: L R I I, 1993.

Trull, Joe E \& Carter, James E. Etika Pelayanan Gereja. Jakarta: BPK Gunung Mulia, 2014.

Tucker, Mary Evelyn \& Grim, John A. Agama, Filsafat, \& Lingkungan Hidup. Yogyakarta: Kanisius, 2003.

Tuhumury, Nelly P. Strategi Unggul Pemulihan Gereja. Tangerang: PT. Matana Publishing Utama, 2015.

Udau, Surendra I. "Peningkatan Pertumbuhan Rohani Perkaria." Skripsi S.Th, Sekolah Tinggi Ttheologia Tenggarong, 2008.

Van Beek, Aart Martin. Konseling Pastoral Sebuah Buku Pegangan Para Penolong Di Indonesia. Semarang: Satya Wacana,1987.

Warren, Rick. Untuk apa Aku Ada Didunia Ini? Jakarta: IMANUEL Publishing House, 2013.

Wiersbe, Warren W. Yakin Di Dalam Kristus. Bandung: Kalam Hidup, 1982.

Wijaya, Hengki (ed.). Metodologi Penelitian Pendidikan Teologi. Makassar: Sekolah Tinggi Theologia Jaffray, 2016.

Winarno, S. Dasar dan Teknik Research. Bandung: Tarsitu, 1978. 